NASA Technical Memorandum 100284

AIAA-88-0287

\title{
Measurement of Local Convective Heat Transfer Coefficients from a Smooth and Roughened NACA-0012 Airfoil: Flight Test Data
}

James E. Newton and G. James VanFossen

Lewis Research Center

Cleveland, Ohio

and

Phillip E. Poinsatte and Kenneth J. DeWitt

The University of Toledo

Toledo, Ohio

Prepared for the

26th Aerospace Sciences Meeting

sponsored by the American Institute of Aeronautics and Astronautics Reno, Nevada, January 11-14, 1988

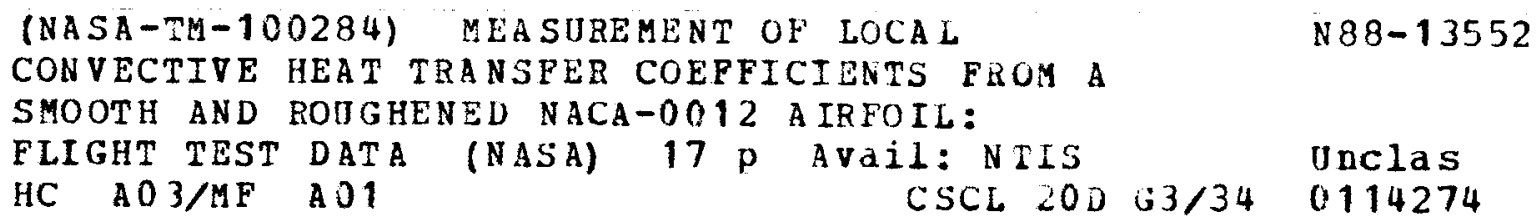


MEASUREMENT OF LOCAL CONVECTIVE HEAT TRANSFER COEFFICIENTS FROM A SMOOTH AND ROUGHENED NACA-0012 AIRFOIL: FLIGHT TEST DATA

\author{
James E. Newton* \\ G. James Van Fossen \\ NASA Lewis Research Center \\ cleveland, Ohio 44135 \\ Phillip E. Poinsatte** \\ Kenneth J. De Witt ${ }^{\star \star *}$ \\ Dept. of Chemical Engineering \\ The University of Toledo \\ Toledo, Ohio 43606
}

\section{Abstract}

wind tunnels typically have higher free stream turbulence levels than are found in flight. Turbulence intensity has been measured to be $0.5 \%$ in the NASA Lewis Icing Research Tunnel (IRT) with the cloud making sprays off and around $2 \%$ with cloud making equipment on. Turbulence intensity for flight conditions was found to be too low to make meaningful measurements $(<0.1 \%)$ for smooth air. This difference between free stream and wind tunnel conditions has raised questions as to the validity of results obtained in the IRT. one objective of these tests was to determine the effect of free stream turbulence on convective heat transfer to a smooth and rough airfoil. Another objective was to obtain needed heat transfer data for the NASA Lewis LEWICE ice growth prediction code.

These tests provide in-flight heat transfer data for a NACA-0012 airfoil with a $533 \mathrm{~cm}$ (21 inch) chord. Future tests will measure heat transfer from the same airfoil in the Lewis Icing Research Tunnel. Roughness was obtained by the attachment of small, $2 \mathrm{~mm}$ diameter hemispheres of uniform size to the airfoil in three different patterns. Heat transfer measurements were recorded in flight on the NASA Lewis Twin otter Icing Research Aircraft. Measurements were taken for the smooth and roughened surfaces at various aircraft speeds and angles of attack up to four degrees. Results are presented as Frossling number versus position on the airfoil for various roughnesses and angles of attack.

\section{Nomenclature}

A surface area of gage

c chord length

d equivalent leading edge diameter

Fr $r_{C}$ Frossling number based on chord

Fr ${ }_{d}$ Frossling number based on equivalent diameter

$h_{\text {con }}$ convective heat transfer coefficient

$\mathrm{k}$ thermal conductivity of air

$M$ Mach number

$\mathrm{Nu}_{c}$ Nusselt number based on chord

$\mathrm{Nu} \mathrm{C}_{\mathrm{d}}$ Nusselt number based on equivalent diameter

\footnotetext{
* Deceased

$\star *$ Graduate student

* Professor, Chemical Engineering
}

$Q_{E I}$ electric power input to heater

$Q_{\text {end }}$ heat loss from unguarded end of gage

Q gap heat loss through gap

$Q_{\text {rad heat loss due to radiation }}$

$\mathrm{Re}_{c}$ Reynolds number based on chord

$\mathrm{Re}_{\mathrm{d}}$ Reynolds number based on equivalent diameter

$T_{t}$ total temperature

$\mathrm{T}_{\mathrm{w}}$ measured gage temperature

$v$ velocity

$\sigma \quad$ Stephan-Boltzman constant

$\mu \quad$ viscosity of air

$\delta$ density of air

$\epsilon$ surface emissivity of polished aluminum

\section{Introduction}

The hazards of aircraft icing are well known. The affect on flow characteristics, especially the reduction of maximum lift and increase of drag on an iced airfoil are documented in references 1-5. A thermal analysis of ice accretion shows that convective heat transfer is a significant factor in the icing process. When supercooled water drops from a cloud strike an airfoil or engine inlet lip, the heat of fusion must be removed before they can turn to ice. If the convective, conductive and evaporative cooling, as well as the warming of impinging droplets, can sufficiently overcome the kinetic heating and remove enough heat from the water droplets on the airfoil surface, then ice will form 6 , The dominant term in this heat balance is convective cooling.

Therefore icing facilities and ice accretion modeling codes must accurately reproduce and simulate convective heat transfer in natural icing conditions. Wind tunnels typically have higher free stream turbulence levels than are found in flight. Turbulence intensity has been measured to be $0.5 \%$ in the NASA Lewis Icing Research Tunnel (IRT) with cloud making sprays off, and around $2 \%$ with cloud making equipment (nozzle atomizing air only) operating. Turbulence intensity for smooth air flight conditions measured during this study have been found to be too low to make meaningful measurements $(<0.1 \%)$. Somewhat higher levels $(0.2-0.4 \%)$ were obtained in rough air below a layer of cumulus clouds. This difference between free stream and wind tunnel turbulence has raised questions as to the validity of results obtained in icing wind tunnels. 
One objective of the present tests is to determine the effect of free stream turbulence on convective heat transfer to a smcoth and roughened airfoil. A second objective of this work is to obtain much needed heat transfer data both for NASA Lewis' LEWICE ${ }^{8}$ ice growth prediction code and to describe the fluid and thermal physics occurring during the icing process. The NASA code currently uses cylinder in crossflow heat transfer data for the stagnation region and flat plate heat transfer coefficients for the rest of the airfoil surface. The present tests provide flight test heat transfer data for a NACA0012 airfoil for both a smooth surface and three quantifiable roughness patterns.

Little data presently exists on convective heat transfer from an airfoil. A NACA study (1946-1951) 9110 compared inflight convective heat transfer from an airfoil, in clear air and during icing conditions, with results from the IRT. For the flight data two separate airfoils, a NACA-0012 and a NACA 65,2-016, were tested at zero angle of attack. Only the 65,2-016 was subsequently tested in the IRT.

In the "flat plate" region (i.e. the region away from the stagnation area) the data showed a substantial difference between flight and IRT heat transfer on the forward portion of the airfoil where the boundary layer was laminar. The IRT data was over $30 \%$ higher than the flight data. This difference has been attributed to the higher turbulence intensities present in the IRT. This conclusion is also supported by the fact that the flight and IRT data agreed fairly well on the downstream portion of the airfoil where the boundary layer was assumed to be fully turbulent.

Besides being restricted to a zero angle of attack, two other factors limit the usefulness of the data for computer code predictions. First, the data is incomplete and somewhat inconsistent in the stagnation region, the area where ice growth initiates. Secondly, this data was not taken for a rough surface, which can significantly alter boundary layer characteristics and thus the convective heat transfer. Roughness, the result of early ice growth, may force a laminar boundary layer into transition in the ice formation zone. This behavior was observed in recent experiments performed on a cylinder in crossflow under different turbulence and roughness conditions 11 . Hence the background turbulence of the IRT may not hinder the simulation of airfoil ice accretion in flight.

Heat transfer coefficients on a smooth NACA-0012 airfoil in a subsonic wind tunnel, as well as on a five minute ice accretion shape were measured in reference 12. The smooth airfoil measurements were taken at various angles of attack (-8 through +8 degrees) and for a chord based Reynolds Number range of $7.6 \times 10^{5}-2.0 \times 10^{6}$. While the zero degree angle of attack data agreed generally with the NACA study, the data showed a much larger angle dependence on the suction side as compared to the pressure side. The data also demonstrated a Nusselt Number increase proportional to the square root of the Reynolds Number.

The present study focused convective heat transfer measurements on a NACA-0012 airfoil. The NACA-0012 was chosen because it is a symmetric profile that is commonly used in helicopter main rotor and tail rotor applications where ice growth is not controlled by electric heating or pneumatic boots. Local heat transfer coefficients were calculated from measurements taken on a smooth and roughened NACA-0012 airfoil with a 0.533 meter (21 inch) chord length. Roughness was obtained by the attachment of small hemispheres of uniform size (2 $\mathrm{mm}$ diameter) onto the airfoil in a set and reproducible pattern. Three separate position patterns, similar to those employed by Schlicting ${ }^{13}$ in his boundary layer work, were used. These patterns were chosen to facilitate numerical modeling of the roughness in various computer codes. Heat transfer measurements were recorded in flight on the NASA Lewis Twin otter Icing Research Aircraft. Data were collected for smooth and roughened surfaces at various aircraft speeds and angles of attack up to four degrees. Results are presented as Frossling Number versus position on the airfoil for various roughnesses and angles of attack. Also stagnation region data is compared with Frossling's cylinder in crossflow solution ${ }^{14}$. For comparison purposes, similar tests are also planned in the NASA Lewis Icing Research Tunnel.

\section{Aircraft}

The NACA-0012 airfoil was flown atop the NASA-Lewis Twin otter Icing Research Aircraft. The aircraft with the airfoil mounted is shown during an aerodynamic check flight in figure 1. The Twin otter is a typical twin engine commuter type aircraft powered by two 550 shaft horsepower turboprop engines. The maximum sustainable speed with the NACA-0012 research airfoil mounted was around 69$\mathrm{m} / \mathrm{sec}$ (135 knots) at 1585-2250 meters (5200-7400 feet) pressure altitude and a temperature range of $289-294 \mathrm{~K}\left(60-70^{\circ} \mathrm{F}\right)$. The airfoil was mounted on the aircraft by attaching the lower end of it to a column that extended through the research hatch to the floor of the fuselage. The upper end of the airfoil was secured by flying wires that were attached to the sides of the fuselage.

Airspeed was measured using the pitot-static probe built into the boom attached to the nose of the aircraft shown in figure 1 .

Angles of attack and yaw were measured using four pressure sensing ports in the hemispherical tip of the boom. The pressure difference from the two vertically opposed pressure taps was calibrated to measure aircraft angle of attack by comparing it to deck angle measured with an inclinometer. The zero yaw delta-p obtained from the 
horizontally opposed pressure taps was calibrated by aligning a string attached to the nose of the aircraft which followed the airstream with the aircraft centerline. The slope of the yaw delta-p versus yaw angle was assumed to be the same as that for the angle of attack.

Free stream static temperature was measured with a commercially available temperature probe which contained a platinum resistance thermometer in a specially designed scoop housing. The manufacturer supplied calibration data to obtain static temperature from the recovery temperature measured by the probe and the true airspeed.15 Total temperature was calculated using the one-dimensional energy equation for a perfect gas under isentropic conditions.

A previous calibration of airspeed measured at the boom versus airspeed measured at the location of the airfoil was used to obtain free stream velocity, total temperature and static pressure at the test airfoil location.

\section{Test airfoil}

Heat transfer measurements were made on a NACA-0012 airfoil that was designed specially for that purpose. The airfoil had a chord of $533 \mathrm{~cm}$ (21 inches) and a span of $1.8 \mathrm{~m}$ (6 feet). The airfoil was constructed of mahogany and had two spars of square, hollow, steel tubing imbedded in it.

An array of heat transfer gages was located in a removable section at the center of the span. The gages were constructed of aluminum and were $6.60 \mathrm{~cm}$ (2.60 inches) long in the spanwise direction, $0.476 \mathrm{~cm}(0.1875$ inch) wide in the flow direction, and $0.318 \mathrm{~cm}(0.125$ inch) deep. Each gage had a groove machined into its edge which contained a type E (chromel-constantan), stainless steel sheathed, closed, grounded ball thermocouple which was held in place with an aluminum filled epoxy. A commercially available, thin foil heater was fastened to the back of each gage with a pressure sensitive adhesive. The heat transfer gages were held in place with an epoxy that was filled with hollow glass microspheres and colloidal silica which made final contouring to the airfoil profile easier. Guard heaters were located beneath the heat flux gages to keep heat from leaking out the back side of the airfoil. The airfoil and epoxy around the gages were sprayed with a thin layer of epoxy to seal them from moisture. The surface of the gages was not coated but was polished to a high luster with a polish made for aluminum. Figure 2. shows a cross section of the airfoil and the location of the heat transfer gages. Table I gives the surface distance from the geometric stagnation point to the center of each gage and its heat transfer surface area.

The airfoil actually contained 28 heat flux gages but only 12 gages in the stagnation region were used in these tests due to difficulty with the automatic controller and data acquisition system. It was felt that the gages in the stagnation region were of the most interest because this is the area where the ice initiates. of these 12 gages only 10 were used to report data; gages 1 and 12 were used as guard heaters to limit the amount of heat leaked from the measuring gagies.

The airfoil was also instrumented with two static pressure taps. These taps were located on opposite sides of the airfoil at the $12 \%$ chord position. They were used to obtain a measure of angle of attack but were not calibrated for that purpose.

Surface roughness was added to the airfoil by fastening hemispheres of silver alloy to the surface with cyanoacrylic adhesive. The hemispheres were $2 \mathrm{~mm}$ in diameter and were attached to the airfoil in three different patterns. A photograph of a typical pattern is shown in figure 3 . Figure 4 shows sketches of the location of the roughness elements relative to the heat flux gages for the three patterns. The thermal resistance of the gage surface was not altered significantly because of the sparse spacing of the elements and the high conductivity of the silver alloy. No attempt was made to account for the presence of the roughness elements in the data reduction.

\section{Data acquisition system}

Data collection and recording was controlled by a microcomputer. All parameters necessary to calculate aircraft true airspeed, total temperature, pressure altitude, angles of attack and yaw were scanned by a commercially available unit which contained a multiplexer, signal conditioning amplifiers, and a 12-bit analog to digital converter. Voltages and currents from the heat flux gages were also digitized with this unit. Digitized signals from this unit were passed to the microcomputer which scanned and recorded each channel 10 times for each data point. Thermocouple extensions were

terminated at a constant temperature reference block whose temperature was read with a calibrated platinum resistance thermometer. Individual thermocouple channels were switched, using a relay type multiplexer, to a digital multimeter that was capable of reading down to 1 microvolt. The IEEE-488 output from this multimeter was then recorded by the microcomputer. Each thermocouple channel was also scanned and recorded 10 times.

\section{Test procedure}

\section{Turbulence measurements}

Turbulence measurements were made on two different flights. The first flight was a preliminary test without the test 
airfoil in place to determine if turbulence from any part of the aircraft structure would interfere with the heat transfer measurements. A constant temperature hot wire was mounted about 0.9 meter ( 3 feet) above the fuselage in the same position as the test airfoil heat flux gages. The aircraft was flown during daylight both in smooth air and under a layer of cumulus clouds. The second flight took place in darkness with the test airfoil in place. For this test, the hot wire was mounted about 2.8 meters ( 9 feet) forward of the airfoil and slightly offset from the aircraft centerline. For both flights the hot wire was operated in the uncalibrated mode as described in reference 16 . To obtain the bridge voltage at zero velocity, the hot wire probe was covered with a plastic cylinder and allowed to come to equilibrium temperature with the air stream.

At very low turbulence intensities (less than about $0.2 \%$ ), hot wire measurements are subject to several sources of errors that are not important at higher intensities. vibrations of the prongs that the wire is mounted on and vibrations of the wire itself are among the causes of high frequency fluctuating signals that can be interpreted as turbulence if one only measures the bridge rms voltage (spectral analysis of the signal is required in order to determine if these false signals are present). To eliminate some of the effects of these false signals, the bridge voltage was run through a low pass filter that was set to cut the signal at frequencies above $5 \mathrm{kHz}$. For both flights, the level of turbulence intensity in smooth air was measured to be around $0.1 \%$. From experience with hot wire equipment in low turbulence wind tunnels and examination of the bridge signal on an oscilloscope, it was felt that the turbulence intensity for these flights was as close to zero as one can get even though the numbers from the hot wire equipment indicate otherwise. For the flight under the layer of cumulus clouds, the intensity was measured to be between 0.2 and $0.4 \%$. This increased intensity was probably due to large scale fluctuations the aircraft flew through. It was determined from the hot wire measurements that turbulence generated by the aircraft structure was not a problem and that there was no change in the intensity at any of the different flight conditions.

\section{Heat transfer measurements}

All heat transfer data acquisition flights were made in darkness to avoid solar radiation on the gages and airfoil. Flights were conducted at an arbitrary altitude that provided smooth atmospheric conditions. At low speeds, flaps were deployed to minimize the aircraft deck angle. At $36 \mathrm{~m} / \mathrm{sec}$ (70 knots) the measured angle of attack was about 1.5 degrees. This small angle of attack resulted in a slightly swept back test airfoil; this effect was ignored in analysis of the data. When steady conditions were established, the heaters were all adjusted to a constant temperature which was typically in the range of $306-314 \mathrm{~K}$ $\left(90-105^{\circ} \mathrm{F}\right)$. The heat flux gages were operated in the constant temperature mode. The temperature of each gage was controlled by a circuit that sensed thermocouple voltage, amplified it, compared that to a reference voltage and adjusted the heater voltage to maintain the desired temperature. The gain of each amplifier could be changed to adjust the temperature of individual gages. The reference voltage was common to all circuits and could be changed to increase or decrease the temperature of all gages simultaneously. When steady conditions were reached, data recording was initiated. About two minutes was required to obtain and record the required 10 scans of all data channels. To obtain data for various angles of attack on the research airfoil, the pilot yawed the aircraft (aircraft yaw = research airfoil angle of attack) using a combination of rudder and aileron. The difference in pressure between the two static pressure taps on the airfoil gave a measure of the angle of attack; this quantity was recorded with the other data. Figure 5 is a plot of aircraft yaw angle measured from the boom delta-p versus the pressure difference between the two static taps on the airfoil made dimensionless by dividing by the dynamic pressure $\left(\delta \mathrm{v}^{2} / 2\right)$. This plot gives a measure of the scatter in the angle of attack. The scatter in the abscissa is the accuracy with which the pilot could set and hold the aircraft yaw.

\section{Data reduction}

The average heat transfer coefficient from each gage was obtained from the applied heater voltage and current, and the temperature difference between the gage and the calculated free stream total temperature. Since only the convective heat transfer was desired, the radiation heat loss had to be subtracted from the total electric power input to each heater. Further, the heater gages embedded in the airfoil were secured in place and separated from each other by an epoxy resin. Some heat was conducted from the edges of each gage, through the epoxy and convected from the surface of the foil in the gaps between gages and from the unguarded ends of the gages. These losses were also subtracted from the electric power. Therefore, the local convective heat transfer coefficient for each aluminum heater gage was calculated from:

$$
\mathrm{h}_{\text {con }}=\frac{Q_{E I}-Q_{\text {rad }^{-}} Q_{\text {gap }}-Q_{\text {end }}}{A\left(T_{W}-T_{t}\right)}
$$


where $Q_{E I}$ (voltage $x$ current) is the total electric power input to each heater. The quantity $Q_{\text {rad }}$ is the radiation heat loss, which is estimated by:

$$
Q_{\text {rad }}=\sigma A \epsilon\left(T_{W}{ }^{4}-T_{t}{ }^{4}\right)
$$

A value of 0.045 was used for $\epsilon$, the emissivity of polished aluminum. and $Q_{\text {end }}$ are the heat loses through the epoxy gaps separating the aluminum gages and the unguarded ends of the heaters. These were obtained from an exact solution for heat conduction in a rectangle with appropriate boundary conditions as detailed in reference 11 . The remaining quantities are: $A$, the surface area of each aluminum gage, $T_{W}$, the measured gage temperature, and $T_{t}$, the total temperature calculated from the measured static temperature and the true airspeed, i.e.

$$
T_{t}=T_{s}\left(1+M^{2} / 5\right)
$$

where $M$ is the Mach Number. Two Frossling Numbers were employed in this analysis, one based on chord length and the other based on an equivalent leading edge diameter. This equivalent diameter is defined as the diameter of a cylinder inscribed in the leading edge of the airfoil. The Frossling Number based on chord was calculated as:

$$
F r_{C}=\frac{N u_{C}}{\sqrt{ } \operatorname{Re}_{C}}=\frac{\left(h_{\text {con }} c / k\right)}{\sqrt{ }(\delta \mathrm{vc} / \mu)}
$$

where $c$ is the 0.533 meter (21 inch) chord length. The Frossling Number based on equivalent diameter was calculated as:

$$
F r_{d}=\frac{N u_{d}}{\sqrt{ } e_{d}}=\frac{\left(h_{c o n} d / k\right)}{\sqrt{ }(\delta v d / \mu)}
$$

where the equivalent diameter, $d$, for 19 NACA-0012 airfoil is $3.16 \%$ of the chord 17 or $1.69 \mathrm{~cm}(0.664$ inch) for the airfoil tested. The density, $\delta$, was calculated from the ideal gas relation for air using the static temperature and pressure at the test airfoil location. velocity was the calculated true airspeed at the test airfoil location. The thermal conductivity, $k$, and viscosity, $\mu$, were obtained as functions of temperature from the air data of reference 18. These thermal properties were evaluated at the film temperature given by:

$$
T_{f}=\left(T_{W}+T_{t}\right) / 2 \text {. }
$$

\section{Error analysis}

An error analysis according to the method of $\mathrm{Kline}$ and McClintock ${ }^{19}$ was performed on each of the calculated local convective heat transfer coefficients, $h_{\text {con }}$ The exrors for each gage were similar and averaged around 15\%. The majority of this error was found to be due to uncertainty in the gap heat loss term because the thermal conductivity of the epoxy gaps was not known and had to be estimated. This would not be a random error but would tend to bias the data either high or low.

\section{Results and Discussion}

In this section heat transfer data for smooth and roughened airfoil surfaces will be presented as Frossling number based on chord length versus dimensionless surface distance from stagnation point (s/c). These results will be presented for nominal 0,2 , and 4 degree angles of attack, and for various Reynolds numbers in the range $1.24 \times 10^{6}$ to $2.50 \times 10^{6}$. Table 2 contains the Frossling numbers for all gages, Reynolds numbers, and angle of attack for data points taken. A comparison will be made of the present data with previous airfoil heat transfer work and with an analytical solution for a cylinder in cross flow.

\section{Smooth airfoil}

Figure 6 shows Frossling number based on chord as a function of s/c for the smooth airfoil at 0 degree angle of attack for several Reynolds numbers. The data plotted in this manner collapses onto a single curve which shows that the heat transfer coefficients are proportional to the square root of Reynolds number. The solid line on the figure represents the averaged, smooth-surface, zero degree angle of attack data and will be plotted on subsequent figures for reference. As expected the Frossling number is greatest at the stagnation point, an average value of 4.3 being observed, and then trailing off smoothly to an average value of 1.0 at $\mathrm{s} / \mathrm{c}$ of 8.3 . The "bump" at $\mathrm{s} / \mathrm{c}=4.8$ cannot be explained; there are no obvious roughnesses or steps in the surface at this or any other point. Perhaps there is a subtle anomaly in the profile at this point that has not been detected.

Defining Frossling number in terms of an airfoil leading edge equivalent diameter allows comparison of Frossling's analytical solution for heat transfer in the stagnation region of a circular cylinder 14 with the present data. The average Frossling number based on leading edge equivalent diameter for the smooth airfoil was found to be 0.76 , roughly $22 \%$ lower than the 0.945 value predicted by Frossling's cylinder solution. Frossling's analytical results are often used with an equivalent leading edge diameter to compute heat transfer in the stagnation region for airfoils and turbine blades but, to our knowledge, no one has ever conducted an experiment to prove the validity of this method.

Figure 7 is a plot of Frossling number based on chord against s/c for the smooth airfoil at a 2 degree angle of attack. Data for the suction side of the airfoil are represented by the positive s/c values. This convention will be maintained 
throughout this report. The data again collapses onto a single curve and illustrates good agreement with the $\sqrt{ } \mathbf{R e}_{C}$ dependence. Comparison with the 0 degree smooth foil data shows no notable difference.

Figure 8 shows Frossling number for a smooth airfoil at 4 degrees angle of attack. Again the data for all Reynolds numbers can be represented by a single curve. Comparing with 0 and 2 degree data, shows very little angle dependence save a slight increase (11\%) on the leading edge and a slight decrease (6\%) on the first gage of the pressure side of the airfoil. This behavior can be explained by the movement of the aerodynamic stagnation point toward the pressure side with increasing angle of attack. This changes the radius of curvature at the aerodynamic stagnation point; the stagnation region sees an effectively larger equivalent diameter and this results in a lower heat transfer coefficient. The flow is then highly accelerated around the leading edge increasing heat transfer at the geometric stagnation point.

\section{Leading edge roughness}

Figures 9,10, and 11 show Frossling number based on chord versus $s / c$ for an airfoil with roughness elements attached to the leading edge, as shown in figure $4 \mathrm{~b}$.), for angles of attack equal to 0,2 , and 4 degrees, respectively. The roughness element row positions are denoted by the arrows below the abscissa. Compared with data from the smooth airfoil, the leading edge roughness increases the heat transfer an average of $8 \%$ at the stagnation point but it returns to essentially the smoothsurface values away from the stagnation region. This increase may be partially explained by the $4 \%$ increase in surface area due to the presence of the hemispherical roughness elements. It could also be attributed to a disturbance of the boundary layer by the relatively huge roughness elements followed by a return to laminar flow sufficiently past the leading edge trip point. Note also that this data set exhibits the same slight angle of attack dependence for the first pressure side and leading edge gages as the smooth airfoil. The first gage on the suction side measures slightly (8\%) higher heat transfer for the 4 degree angle of attack than for 0 or 2 degrees.

\section{Sparse roughness}

Frossling number as a function of $\mathrm{s} / \mathrm{c}$ for the sparse roughness pattern shown in figure $4 \mathrm{c.}$ ) at 0,2 and 4 degrees angle of attack are presented in figures 12,13 , and 14 respectively. smooth airfoil, this data set contains somewhat more scatter but still can be represented by a single curve which is consistent with the $\sqrt{ } \mathrm{Re}_{\mathrm{c}}$ dependence. For the 0 degree angle of attack case, the heat transfer increase at stagnation (gage 4) is 11\%; comparable the leading edge roughness case. Past the stagnation region, the heat transfer exhibits a pattern of increasing at and immediately downstream of the roughness row position and then falling off slightly. At gage 7 , the heat transfer increases by $55 \%$ over the smooth airfoil case, increases to $59 \%$ at gage 8 , then falls to a $52 \%$ increase at gage 9. At gage 10 the next row of roughness elements is encountered. The heat transfer at gages 10 and 11 increases by about $170 \%$ over the no roughness case. The sensitivity of the boundary layer to roughness seems to increase with downstream location.

The angle of attack dependence is also more pronounced for the sparse roughness pattern than the smooth and leading edge roughened cases. For the sparsely roughened airfoil, the Frossling numbers for 2 degrees angle of attack for gages 7 through 11 increase gradually with s/c from 8 to $15 \%$ over the 0 degree case and from 14 to $26 \%$ going from 0 to 4 degrees. Increasing angle of attack causes heat transfer to increase with $\mathrm{s} / \mathrm{c}$ over the 0 degree case. Note that for 4 degrees, the characteristic increase at stagnation and slight decrease on the second gage of the pressure side of the airfoil are also observed.

\section{Dense roughness}

Frossling number versus $s / c$ for the dense roughness pattern (fig. 4 d.)) at 0 , 2 and 4 degrees angle of attack are presented in figures 15, 16, and 17. For the 0 degree angle of attack case, the data points still tend to fall on one curve indicating a $\sqrt{ } e_{C}$ dependence. Increasing the density of roughness elements from the sparse to dense pattern had a dramatic effect on heat transfer downstream. For the 0 degree angle of attack, gage 6 increased 32 and gages 7 and 8 increased an average of $54 \%$ over the sparse roughness case. Further downstream past gage 7 , the density of roughness elements decreases and at gages 10 and 11 , the effect of the increased density of the roughness elements upstream seems to have nearly damped out. This trend indicates that if there is roughness of sufficient magnitude present, the boundary layer is perturbed locally and immediately downstream but, as the density of roughness is lowered in the downstream direction, the heat transfer recovers to a level that is consistent with the sparse roughness pattern.

For the 2 and 4 degree angles of attack there is considerably more scatter in the data than was present in the smooth airfoil cases. At high values of $\mathrm{s} / \mathrm{c}$, the Frossling numbers increase monotonically with Reynolds number; this may indicate a trend away from the $\sqrt{ } R_{c}$ dependence with increasing roughness and angle of attack.

The angle of attack dependence is much more prominent in the dense roughness case compared to other cases tested. A increase from 0 to 2 degrees caused roughly a $20 \%$ increase in Frossling number for the gages between $\mathrm{s} / \mathrm{c}$ of 2 and 5 , while a 4 degree change yielded an increase of roughly 
398. For gages at s/c locations greater than 5, increasing angle of attack from 0 to 2 degrees caused a $15.3 \%$ increase and from 0 to 4 degrees a $27 \%$ increase in Frossling number.

\section{Comparison with other data}

Finally figures 18 and 19 compare the present smooth airfoil results with previously published data. Figure 18 shows the comparison with flight test data for both a NACA-0012 and a NACA 65,2-016 ajrfoils ${ }^{9}$. Aside from a few exceptional points good general agreement is observed, most values agreeing within $10 \%$.

Figure 19 illustrates the comparison of the present smooth airfoil, 0 degree angle of attack flight data with wind tunnel data of reference 12. Relatively good agreement exists up to a s/c value of about 5; however, further down the airfoil Frossling numbers differ by nearly $300 \%$. This could be due to wind tunnel turbulence or roughness of the reference 12 model surface. In a personal communication with the author of reference 12 it was indicated that the surface of their airfoil was "rough".

\section{References}

1. Cebeci, T., "Effects of Environmentally Imposed Roughness on Airfoil Performance", NASA CR-179639, June 1987.

2. Olsen,W. A., Shaw, R. J. and Newton, J. E., "Ice Shapes and the Resulting Drag Increase for a NACA-0012 Airfoil", NASA TN-83556.

3. Bragg, M.B., Gregorek, G.M. and Shaw, R. J., "Wind Tunnel Investigation of Airfoil Performance Degradation Due to Icing", AIAA-82-0582,1982.

4. Korkan, K.D., "Performance Degradation of Propeller/Rotor Systems Due to Rime Ice Accretion" report delivered at NASA Lewis Research Center Icing Analysis Workshop, Feb.8, 1983.

5. Young, A. D., Paterson, J. H., "Aircraft Excerscence Drag," AGARDograph No. 264, July, 1981

6. Messinger, B. L., "Equilibrium Temperature of Unheated Icing Surface as a Function of Air Speed", J. of Aeronautical Sciences Vol.20, p 29, 1953 .

7. Hardy, J. K.,"Protection of Aircraft Against Ice" Royal Aeronautical Society Journal vol 51, p 435, 1947.

8. Ruff, G. A.; "Users Manual for the NASA Lewis Ice Accretion Prediction Code (LEWICE), to be published as a NASA-CR.
9. Neel, C. B. et al.,"The Calculation of Heat Required For Wind Thermal Ice Prevention in Specified Icing Conditions", NACA TN-1472, 1946

10. Gelder, T. F. and Lewis, J. P., "Comparison of Heat Transfer from Airfoil in Natural and Simulated Icing Conditions" NACA TN-2480, 1951.

11. Van Fossen, G. J. et al., "Heat Transfer Distributions Around Nominal Ice Accretion Shapes Formed on a Cylinder in the NASA Lewis Icing Research Tunnel," AIAA paper no. 84-0017 presented at the AIAA 22nd Areospace Sci. Mtg., Reno, NV, Jan 1984 .

also NASA TM-83557

12. Pais, M. R., Singh, S. N. and Zou, L., "Determination of the Local Heat Transfer Characteristics on Glaze Ice Accretions on a NACA-0012 Airfoil," AIAA paper 88-0292, presented at AIAA 26th Aerospace Sci. Mtg., Reno, NV, Jan. 10-14, 1988

13. Schlicting, H., "Experimental Investigation of the Problem of Surface Roughness", NACA TM-823, April 1937.

14. Frossling, N., "Evaporation, Heat Transfer, and Velocity in TwoDimensional and Rotationally Symmetrical Laminar Boundary Layer Flow" NACA TM-1432, 1958.

15. Anon, "Series 154 Total Temperature Sensors for Aircraft Gas Turbine Engine Inlets", Product Data Sheet 2186, Rosemont, Inc. Minneapolis, MN. 1973

16. Anon., "Hot Wire and Hot Film Measurements and Applications," Thermal Systems, Inc., Tech. Bulletin No. 4 , p. 35

17. Abbott, I. H., von Doenhoff, A. E. Stivers, L. S., "Summary of Airfoil Data", NACA Report No. 824, p.71., 1945

18. Hillsenrath, J. et al., "Tables of Thermal Properties of Gases," NBS Circular 564, Nov. 1955.

19. Kline, S. J. and Mcclintock, F. A., "Describing uncertainties in singléSample Experiments," Mechanical Engineering, vol 75, Jan 1953, p 3-8. 
Table 1. Location and surface area of heat transfer gages.

\begin{tabular}{|c|c|c|}
\hline GAGE \# & S/C & $\begin{array}{c}\text { SURFACE } \\
\text { AREA } \\
\text { sq.cm. }\end{array}$ \\
\hline 1 & -0.036 & 3.145 \\
2 & -0.024 & 3.145 \\
3 & -0.012 & 3.145 \\
4 & 0 & 3.187 \\
5 & 0.012 & 3.145 \\
6 & 0.024 & 3.145 \\
7 & 0.036 & 3.145 \\
8 & 0.048 & 3.145 \\
9 & 0.060 & 3.145 \\
10 & 0.072 & 3.145 \\
11 & 0.083 & 3.145 \\
12 & 0.095 & 3.145 \\
\hline
\end{tabular}

Table 2. Frossling number for each gage for all conditions tested.

\begin{tabular}{|c|c|c|c|c|c|c|c|c|c|c|c|c|}
\hline \multirow[b]{2}{*}{$\begin{array}{l}\text { roughness } \\
\text { pattern }\end{array}$} & \multirow[b]{2}{*}{ alpha } & \multirow[b]{2}{*}{$\operatorname{Re}$} & \multicolumn{8}{|c|}{ Gage Number } & \multirow[b]{2}{*}{10} & \multirow[b]{2}{*}{11} \\
\hline & & & 2 & 3 & 4 & 5 & 6 & 7 & 8 & 9 & & \\
\hline $\begin{array}{l}\text { none } \\
\text { none } \\
\text { none } \\
\text { none } \\
\text { none }\end{array}$ & $\begin{array}{r}.027 \\
-.441 \\
-.435 \\
-.127 \\
-.310\end{array}$ & $\begin{array}{l}1291850 \\
1924300 \\
1935420 \\
1935620 \\
2482730\end{array}$ & $\begin{array}{l}3.140 \\
3.027 \\
3.077 \\
2.935 \\
3.016\end{array}$ & $\begin{array}{l}3.959 \\
3.803 \\
3.858 \\
3.691 \\
3.752\end{array}$ & $\begin{array}{l}4.495 \\
4.261 \\
4.332 \\
4.174 \\
4.190\end{array}$ & $\begin{array}{l}3.960 \\
3.787 \\
3.867 \\
3.703 \\
3.798\end{array}$ & $\begin{array}{l}2.899 \\
2.780 \\
2.806 \\
2.716 \\
2.804\end{array}$ & $\begin{array}{l}2.312 \\
2.207 \\
2.208 \\
2.169 \\
2.225\end{array}$ & $\begin{array}{l}2.003 \\
1.915 \\
1.929 \\
1.866 \\
1.938\end{array}$ & $\begin{array}{l}1.167 \\
1.133 \\
1.145 \\
1.122 \\
1.154\end{array}$ & $\begin{array}{l}1.034 \\
1.004 \\
1.003 \\
0.971 \\
0.999\end{array}$ & $\begin{array}{l}0.988 \\
0.954 \\
0.954 \\
0.919 \\
0.925\end{array}$ \\
\hline $\begin{array}{l}\text { none } \\
\text { none } \\
\text { none }\end{array}$ & $\begin{array}{l}-2.60 \\
-2.33 \\
-2.46\end{array}$ & $\begin{array}{l}1285880 \\
1937560 \\
2482670\end{array}$ & $\begin{array}{l}3.151 \\
3.079 \\
3.061\end{array}$ & $\begin{array}{l}3.949 \\
3.845 \\
3.794\end{array}$ & $\begin{array}{l}4.646 \\
4.410 \\
4.289\end{array}$ & $\begin{array}{l}3.906 \\
3.907 \\
3.761\end{array}$ & $\begin{array}{l}2.825 \\
2.694 \\
2.715\end{array}$ & $\begin{array}{l}2.239 \\
2.140 \\
2.150\end{array}$ & $\begin{array}{l}1.892 \\
1.861 \\
1.816\end{array}$ & $\begin{array}{l}1.151 \\
1.111 \\
1.046\end{array}$ & $\begin{array}{l}0.993 \\
0.956 \\
0.930\end{array}$ & $\begin{array}{l}0.958 \\
0.886 \\
0.873\end{array}$ \\
\hline $\begin{array}{l}\text { none } \\
\text { none } \\
\text { none } \\
\text { none }\end{array}$ & $\begin{array}{l}-4.41 \\
-4.49 \\
-4.35 \\
-4.32\end{array}$ & $\begin{array}{l}1273580 \\
1283910 \\
1934040 \\
2465000\end{array}$ & $\begin{array}{l}3.210 \\
3.189 \\
3.106 \\
2.966\end{array}$ & $\begin{array}{l}3.747 \\
3.734 \\
3.504 \\
3.315\end{array}$ & $\begin{array}{l}4.916 \\
4.898 \\
4.749 \\
4.505\end{array}$ & $\begin{array}{l}3.943 \\
3.912 \\
3.727 \\
3.719\end{array}$ & $\begin{array}{l}2.765 \\
2.721 \\
2.620 \\
2.622\end{array}$ & $\begin{array}{l}2.157 \\
2.107 \\
2.071 \\
2.064\end{array}$ & $\begin{array}{l}1.826 \\
1.784 \\
1.736 \\
1.733\end{array}$ & $\begin{array}{l}1.097 \\
1.075 \\
1.031 \\
1.056\end{array}$ & $\begin{array}{l}0.948 \\
0.915 \\
0.903 \\
0.898\end{array}$ & $\begin{array}{l}0.899 \\
0.866 \\
0.824 \\
0.846\end{array}$ \\
\hline $\begin{array}{l}\text { l.e. } \\
\text { l.e. } \\
\text { l.e. }\end{array}$ & $\begin{array}{l}-.568 \\
-.266 \\
-.423\end{array}$ & $\begin{array}{l}1258000 \\
1886310 \\
2424730\end{array}$ & $\begin{array}{l}3.165 \\
3.104 \\
3.156\end{array}$ & $\begin{array}{l}4.069 \\
3.921 \\
3.973\end{array}$ & $\begin{array}{l}4.857 \\
4.662 \\
4.730\end{array}$ & $\begin{array}{l}4.065 \\
3.866 \\
4.014\end{array}$ & $\begin{array}{l}2.938 \\
2.817 \\
2.907\end{array}$ & $\begin{array}{l}2.341 \\
2.251 \\
2.313\end{array}$ & $\begin{array}{l}2.002 \\
1.921 \\
1.898\end{array}$ & $\begin{array}{l}1.181 \\
1.168 \\
1.167\end{array}$ & $\begin{array}{l}1.045 \\
1.004 \\
1.015\end{array}$ & $\begin{array}{l}0.996 \\
0.927 \\
0.949\end{array}$ \\
\hline $\begin{array}{l}\text { l.e. } \\
\text { l.e. } \\
\text { l.e. } \\
\text { l.e. } \\
\text { l.e. }\end{array}$ & $\begin{array}{l}-2.32 \\
-2.34 \\
-2.42 \\
-2.32 \\
-2.31\end{array}$ & $\begin{array}{l}1265320 \\
1878440 \\
1884740 \\
2392890 \\
2396510\end{array}$ & $\begin{array}{l}3.177 \\
3.005 \\
3.031 \\
3.028 \\
3.039\end{array}$ & $\begin{array}{l}4.018 \\
3.771 \\
3.833 \\
3.825 \\
3.817\end{array}$ & $\begin{array}{l}4.872 \\
4.577 \\
4.571 \\
4.519 \\
4.520\end{array}$ & $\begin{array}{l}3.973 \\
3.725 \\
3.766 \\
3.881 \\
3.850\end{array}$ & $\begin{array}{l}2.850 \\
2.692 \\
2.700 \\
2.771 \\
2.867\end{array}$ & $\begin{array}{l}2.246 \\
2.194 \\
2.124 \\
2.443 \\
2.321\end{array}$ & $\begin{array}{l}1.933 \\
1.848 \\
1.830 \\
1.814 \\
1.864\end{array}$ & $\begin{array}{l}1.153 \\
1.078 \\
1.072 \\
1.090 \\
1.039\end{array}$ & $\begin{array}{l}1.009 \\
0.966 \\
0.963 \\
0.975 \\
0.946\end{array}$ & $\begin{array}{l}0.952 \\
0.866 \\
0.878 \\
1.142 \\
0.836\end{array}$ \\
\hline $\begin{array}{l}\text { l.e. } \\
\text { l.e. } \\
\text { l.e. }\end{array}$ & $\begin{array}{l}-4.78 \\
-4.33 \\
-4.37\end{array}$ & $\begin{array}{l}1244970 \\
1879440 \\
2422480\end{array}$ & $\begin{array}{l}3.155 \\
2.998 \\
3.066\end{array}$ & $\begin{array}{l}3.649 \\
3.442 \\
3.506\end{array}$ & $\begin{array}{l}5.158 \\
4.933 \\
5.089\end{array}$ & $\begin{array}{l}4.064 \\
4.208 \\
4.131\end{array}$ & $\begin{array}{l}2.819 \\
2.655 \\
2.860\end{array}$ & $\begin{array}{l}2.181 \\
2.016 \\
2.203 \\
\end{array}$ & $\begin{array}{l}1.863 \\
1.478 \\
1.859 \\
\end{array}$ & $\begin{array}{l}1.128 \\
1.207 \\
1.166\end{array}$ & $\begin{array}{l}1.008 \\
0.953 \\
1.115\end{array}$ & $\begin{array}{l}1.003 \\
0.898 \\
1.216\end{array}$ \\
\hline $\begin{array}{l}\text { sparse } \\
\text { sparse } \\
\text { sparse } \\
\text { sparse }\end{array}$ & $\begin{array}{l}-.272 \\
-.138 \\
-.333 \\
-.304\end{array}$ & $\begin{array}{l}1257300 \\
1884970 \\
1886120 \\
2415640\end{array}$ & $\begin{array}{l}3.254 \\
3.084 \\
3.028 \\
3.085\end{array}$ & $\begin{array}{l}4.160 \\
3.973 \\
3.911 \\
3.920\end{array}$ & $\begin{array}{l}5.044 \\
4.736 \\
4.626 \\
4.662\end{array}$ & $\begin{array}{l}4.205 \\
3.904 \\
3.904 \\
3.936\end{array}$ & $\begin{array}{l}2.989 \\
2.817 \\
2.714 \\
2.807\end{array}$ & $\begin{array}{l}3.487 \\
3.406 \\
3.384 \\
3.487\end{array}$ & $\begin{array}{l}3.071 \\
3.057 \\
3.016 \\
3.142\end{array}$ & $\begin{array}{l}1.728 \\
1.727 \\
1.715 \\
1.774\end{array}$ & $\begin{array}{l}2.577 \\
2.690 \\
2.658 \\
2.837\end{array}$ & $\begin{array}{l}2.502 \\
2.663 \\
2.626 \\
2.816\end{array}$ \\
\hline $\begin{array}{l}\text { sparse } \\
\text { sparse } \\
\text { sparse } \\
\text { sparse }\end{array}$ & $\begin{array}{l}-1.94 \\
-2.32 \\
-2.28 \\
-2.33\end{array}$ & $\begin{array}{l}1250160 \\
1896200 \\
2420490 \\
2461170\end{array}$ & $\begin{array}{l}3.299 \\
3.147 \\
3.110 \\
3.156\end{array}$ & $\begin{array}{l}4.181 \\
3.897 \\
3.905 \\
3.956\end{array}$ & $\begin{array}{l}5.052 \\
4.701 \\
4.685 \\
4.738\end{array}$ & $\begin{array}{l}4.129 \\
3.911 \\
3.970 \\
4.041\end{array}$ & $\begin{array}{l}2.882 \\
2.745 \\
2.798 \\
2.883\end{array}$ & $\begin{array}{l}3.602 \\
3.631 \\
3.771 \\
3.901\end{array}$ & $\begin{array}{l}3.173 \\
3.276 \\
3.444 \\
3.565\end{array}$ & $\begin{array}{l}1.819 \\
1.871 \\
1.991 \\
2.057\end{array}$ & $\begin{array}{l}2.796 \\
2.978 \\
3.237 \\
3.315\end{array}$ & $\begin{array}{l}2.765 \\
2.946 \\
3.232 \\
3.325\end{array}$ \\
\hline $\begin{array}{l}\text { sparse } \\
\text { sparse } \\
\text { sparse } \\
\text { sparse }\end{array}$ & $\begin{array}{l}-4.24 \\
-4.46 \\
-4.44 \\
-4.38\end{array}$ & $\begin{array}{l}1244580 \\
1263380 \\
1890090 \\
2434720\end{array}$ & $\begin{array}{l}3.417 \\
3.342 \\
3.122 \\
3.001\end{array}$ & $\begin{array}{l}3.971 \\
3.914 \\
3.594 \\
3.431\end{array}$ & $\begin{array}{l}5.586 \\
5.499 \\
5.133 \\
4.987\end{array}$ & $\begin{array}{l}4.433 \\
4.322 \\
4.099 \\
4.103\end{array}$ & $\begin{array}{l}3.001 \\
2.935 \\
2.749 \\
2.745\end{array}$ & $\begin{array}{l}4.002 \\
3.865 \\
3.866 \\
4.000\end{array}$ & $\begin{array}{l}3.591 \\
3.473 \\
3.579 \\
3.783\end{array}$ & $\begin{array}{l}2.142 \\
2.049 \\
2.140 \\
2.333\end{array}$ & $\begin{array}{l}3.342 \\
3.218 \\
3.503 \\
3.526\end{array}$ & $\begin{array}{l}3.177 \\
3.062 \\
3.294 \\
3.466\end{array}$ \\
\hline $\begin{array}{l}\text { dense } \\
\text { dense } \\
\text { dense } \\
\text { dense } \\
\text { dense }\end{array}$ & $\begin{array}{r}.100 \\
.885 \\
-.318 \\
-.630 \\
-.335\end{array}$ & $\begin{array}{l}1269450 \\
1276420 \\
1887710 \\
1908240 \\
2446790\end{array}$ & $\begin{array}{l}3.732 \\
3.771 \\
4.010 \\
3.963 \\
4.136\end{array}$ & $\begin{array}{l}4.339 \\
4.328 \\
4.081 \\
3.985 \\
3.962\end{array}$ & $\begin{array}{l}5.072 \\
5.066 \\
4.717 \\
4.696 \\
4.434\end{array}$ & $\begin{array}{l}4.737 \\
4.708 \\
4.421 \\
4.361 \\
4.261\end{array}$ & $\begin{array}{l}3.562 \\
3.576 \\
3.814 \\
3.819 \\
3.891\end{array}$ & $\begin{array}{l}5.424 \\
5.497 \\
5.605 \\
5.564 \\
5.555\end{array}$ & $\begin{array}{l}4.668 \\
4.679 \\
4.740 \\
4.717 \\
4.761\end{array}$ & $\begin{array}{l}2.456 \\
2.484 \\
2.498 \\
2.514 \\
2.562\end{array}$ & $\begin{array}{l}2.590 \\
2.614 \\
2.738 \\
2.710 \\
2.811\end{array}$ & $\begin{array}{l}2.439 \\
2.427 \\
2.572 \\
2.532 \\
2.657\end{array}$ \\
\hline $\begin{array}{l}\text { dense } \\
\text { dense } \\
\text { dense }\end{array}$ & $\begin{array}{l}-2.80 \\
-2.21 \\
-2.34\end{array}$ & $\begin{array}{l}1275150 \\
1929750 \\
2466420\end{array}$ & $\begin{array}{l}3.430 \\
3.543 \\
3.660\end{array}$ & $\begin{array}{l}4.158 \\
4.011 \\
3.952\end{array}$ & $\begin{array}{l}5.026 \\
4.738 \\
4.661\end{array}$ & $\begin{array}{l}4.840 \\
4.759 \\
4.809\end{array}$ & $\begin{array}{l}4.354 \\
4.549 \\
4.821\end{array}$ & $\begin{array}{l}6.295 \\
6.535 \\
6.748\end{array}$ & $\begin{array}{l}5.204 \\
5.402 \\
5.721\end{array}$ & $\begin{array}{l}2.764 \\
2.896 \\
3.124\end{array}$ & $\begin{array}{l}2.891 \\
3.099 \\
3.276\end{array}$ & $\begin{array}{l}2.684 \\
2.899 \\
3.064\end{array}$ \\
\hline $\begin{array}{l}\text { dense } \\
\text { dense } \\
\text { dense }\end{array}$ & $\begin{array}{l}-4.83 \\
-4.24 \\
-4.40\end{array}$ & $\begin{array}{l}1275190 \\
1899520 \\
2439820\end{array}$ & $\begin{array}{l}3.308 \\
3.209 \\
3.283\end{array}$ & $\begin{array}{l}3.740 \\
3.566 \\
3.545\end{array}$ & $\begin{array}{l}5.379 \\
5.215 \\
5.284\end{array}$ & $\begin{array}{l}5.414 \\
5.452 \\
5.699\end{array}$ & $\begin{array}{l}5.138 \\
5.473 \\
5.889\end{array}$ & $\begin{array}{l}7.273 \\
7.356 \\
7.924\end{array}$ & $\begin{array}{l}5.730 \\
5.958 \\
6.460\end{array}$ & $\begin{array}{l}3.030 \\
3.230 \\
3.539\end{array}$ & $\begin{array}{l}3.157 \\
3.383 \\
3.657\end{array}$ & $\begin{array}{l}2.932 \\
3.125 \\
3.381\end{array}$ \\
\hline
\end{tabular}




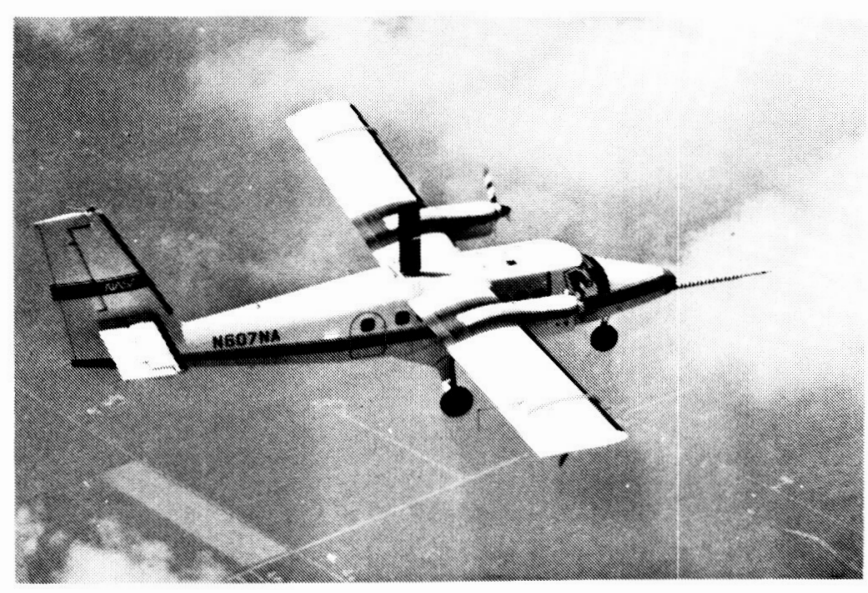

Figure 1. NASA Lewis Icing Research Aircraft with NACA-0012 heat transfer research airfoil.

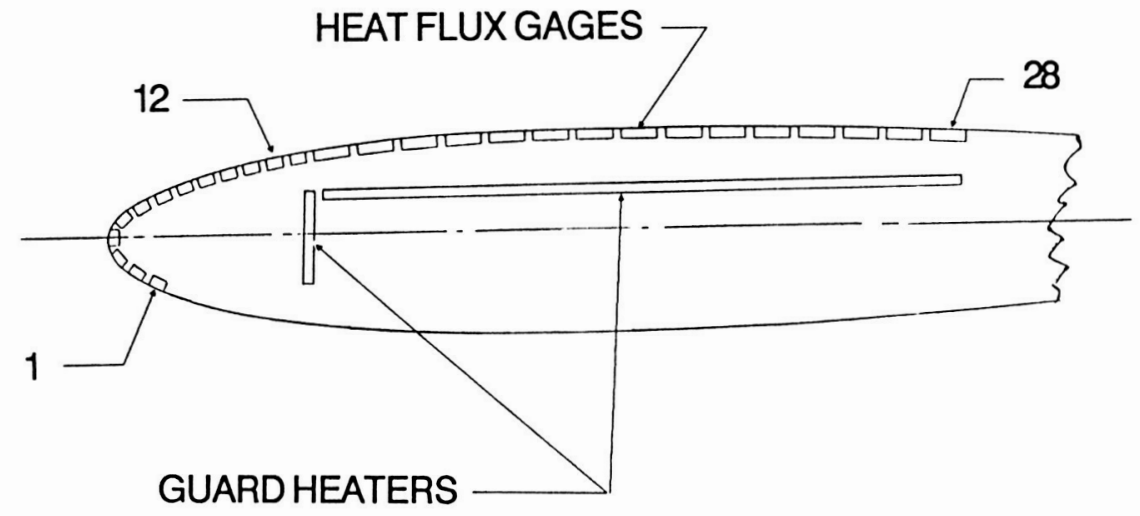

Figure 2. Cross section of NACA- 0012 airfoil with heat flux gages.

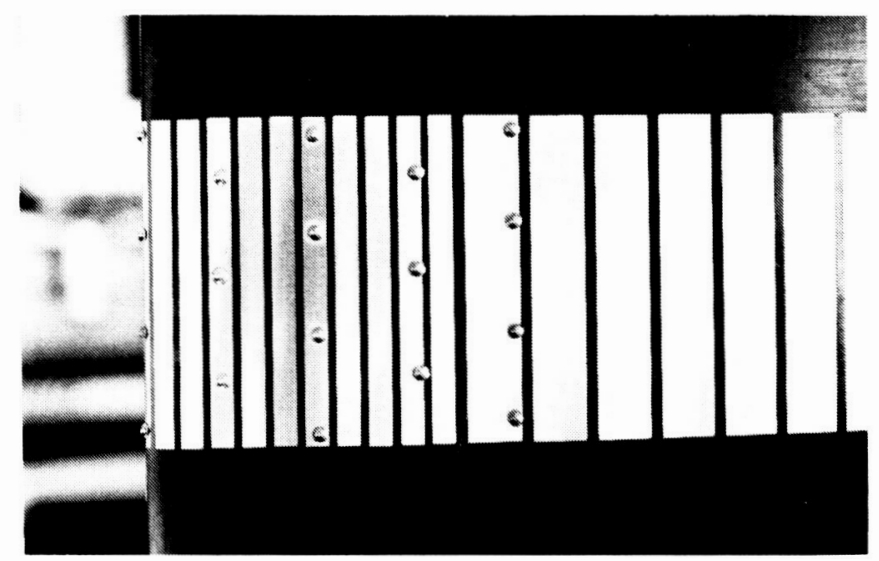

Figure 3. Sparse roughness pattern. 


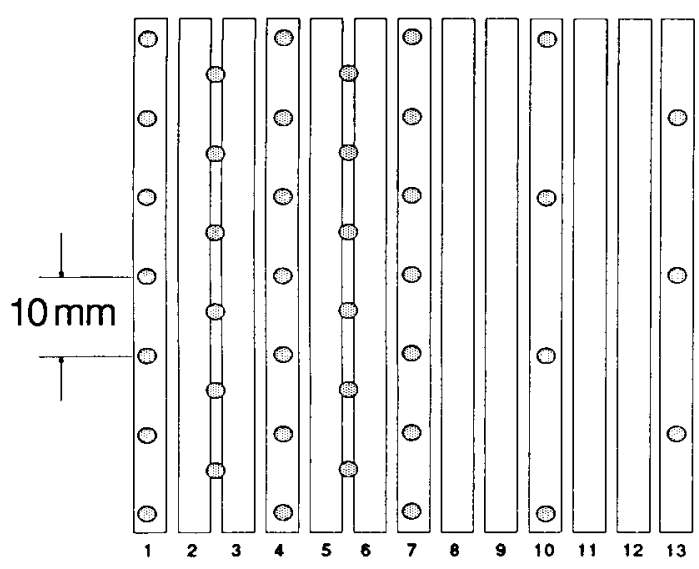

d.) Dense roughness pattern.

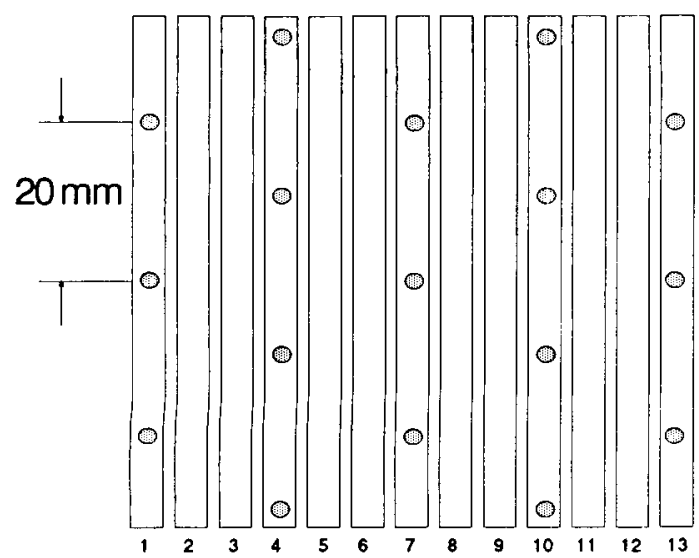

c.) Sparse roughness pattern.

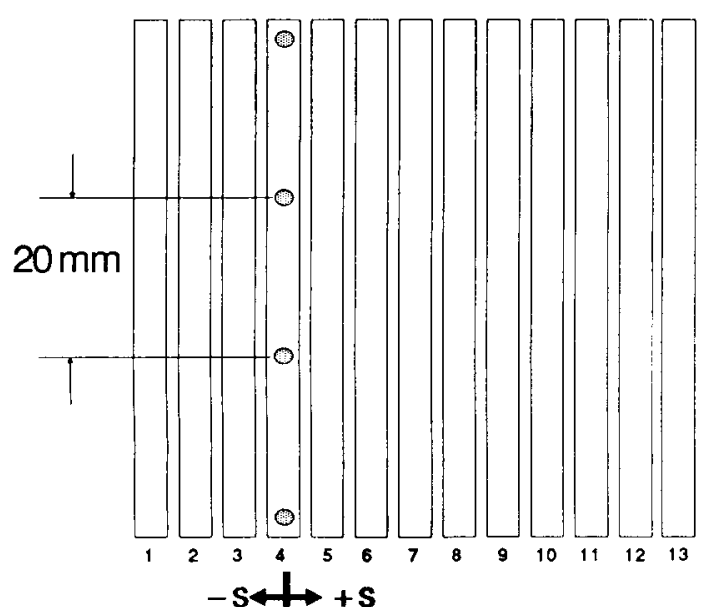

b.) Leading edge roughness pattern.

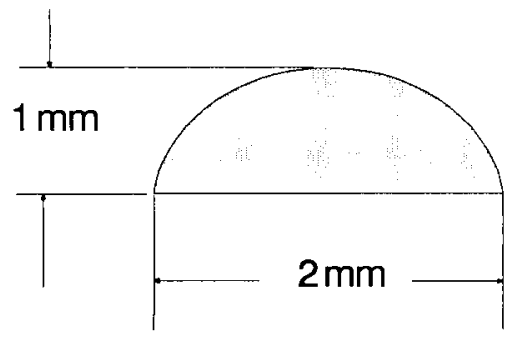

a.) Typical roughness element.

Figure 4. Location of roughness elements relative to heat flux gages.

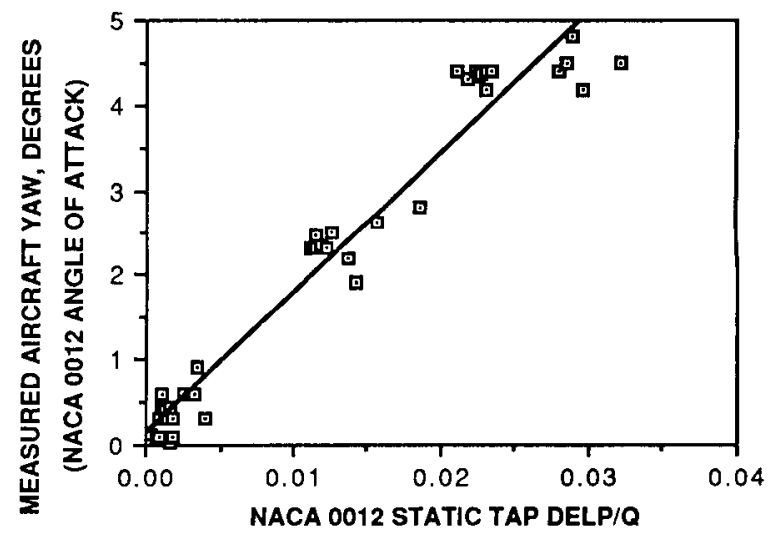

Figure 5. Comparison on angle of attack measurements from airfoil and aircraft instruments. 


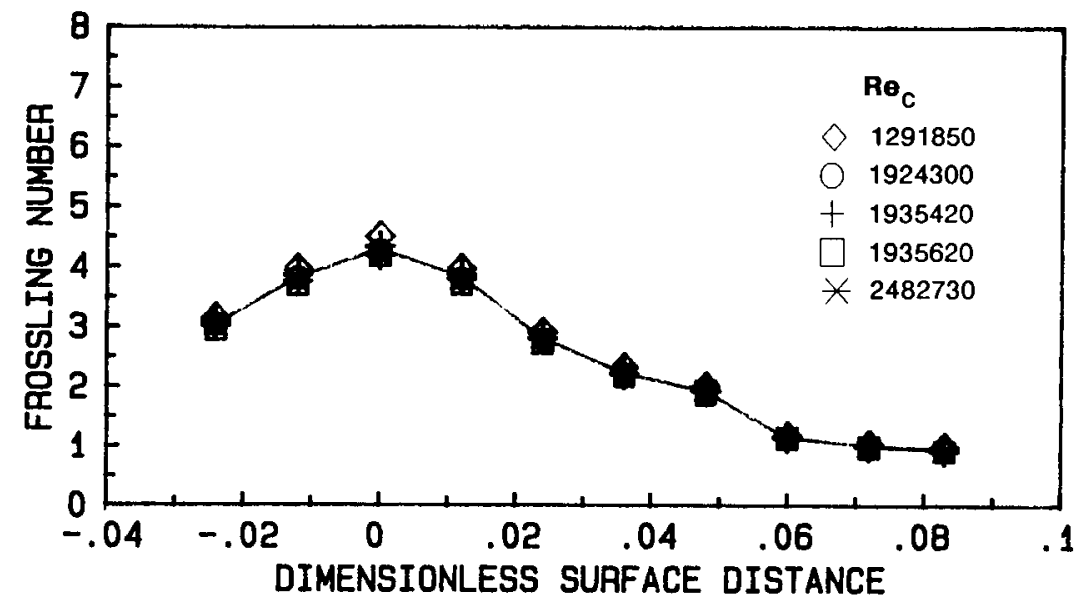

Figure 6. Frossling number based on chord for smooth airfoil, zero degree angle of attack for various Reynolds numbers.

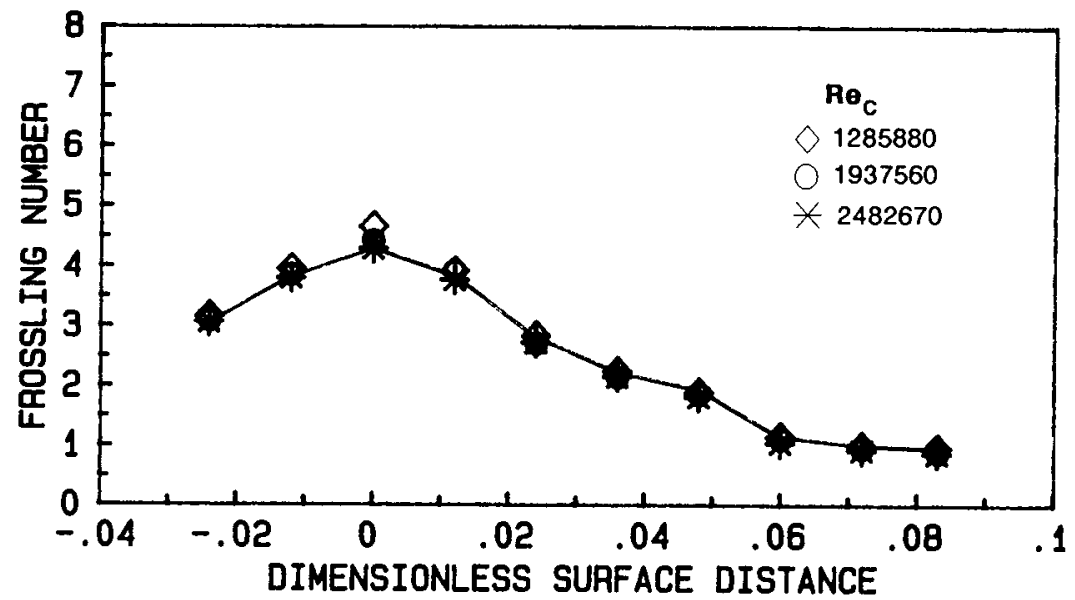

Figure 7. Frossling number based on chord for smooth airfoil, two degree angle of attack for various Reynolds numbers.

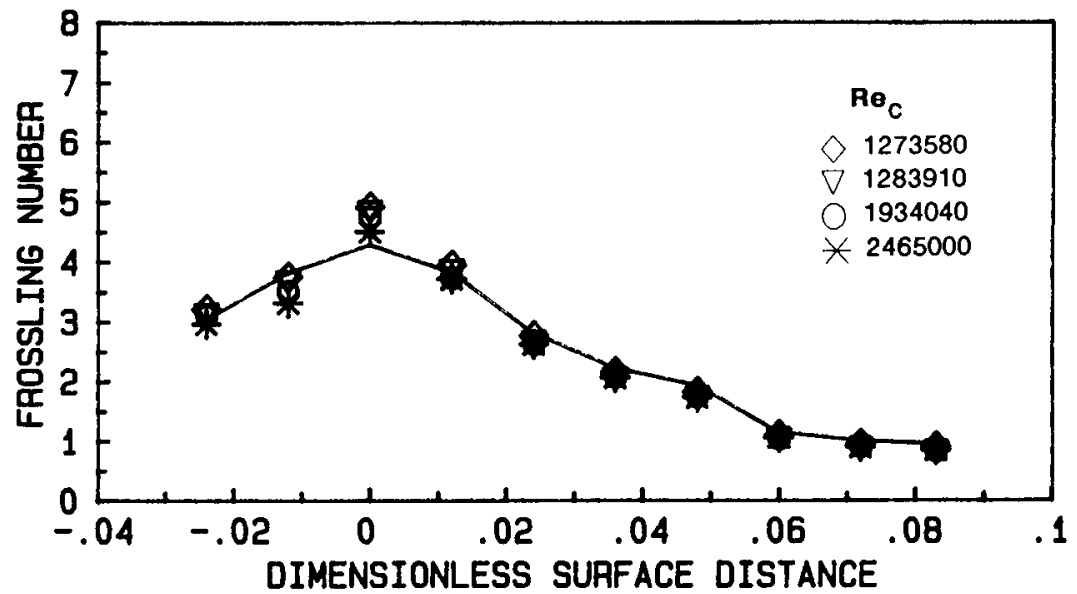

Figure 8 . Frossling number based on chord for smooth airfoil, four degree angle of attack for various Reynolds numbers. 


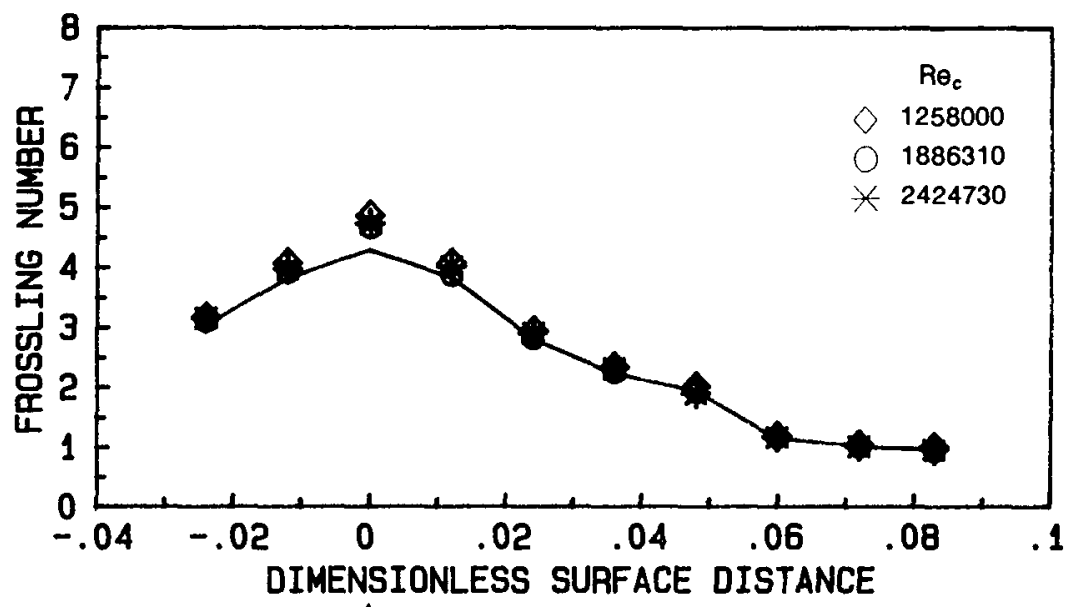

Figure 9. Frossling number based on chord for leading edge roughened aifoil, zero degree angle of attack for various Reynolds numbers.

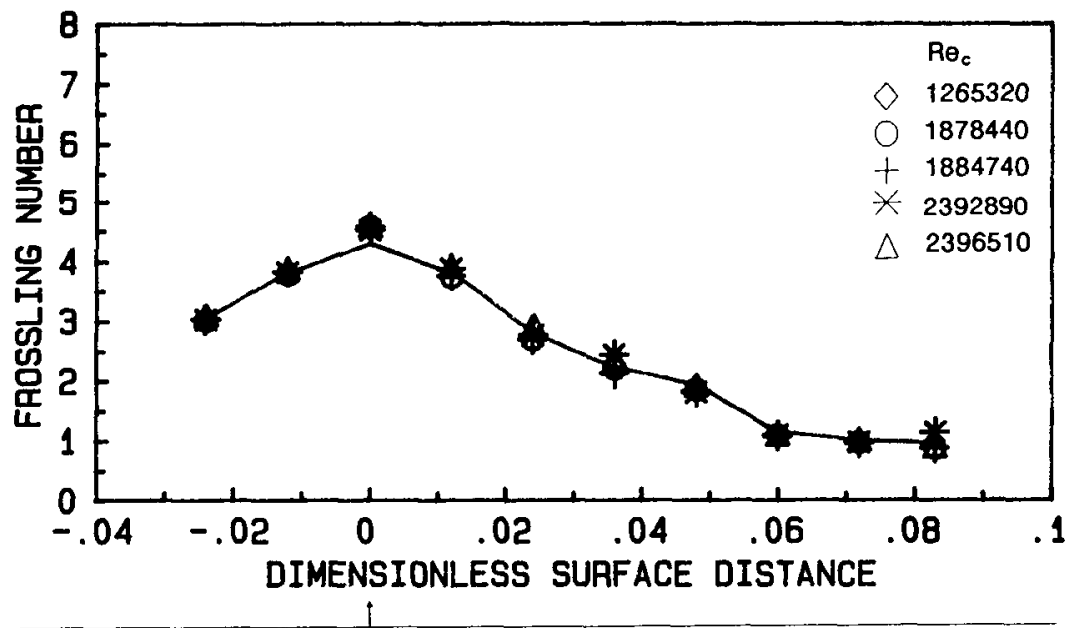

Figure 10. Frossling number based on chord for leading edge rougnened airfoil, two degree angle of attack for various Reynolds numbers.

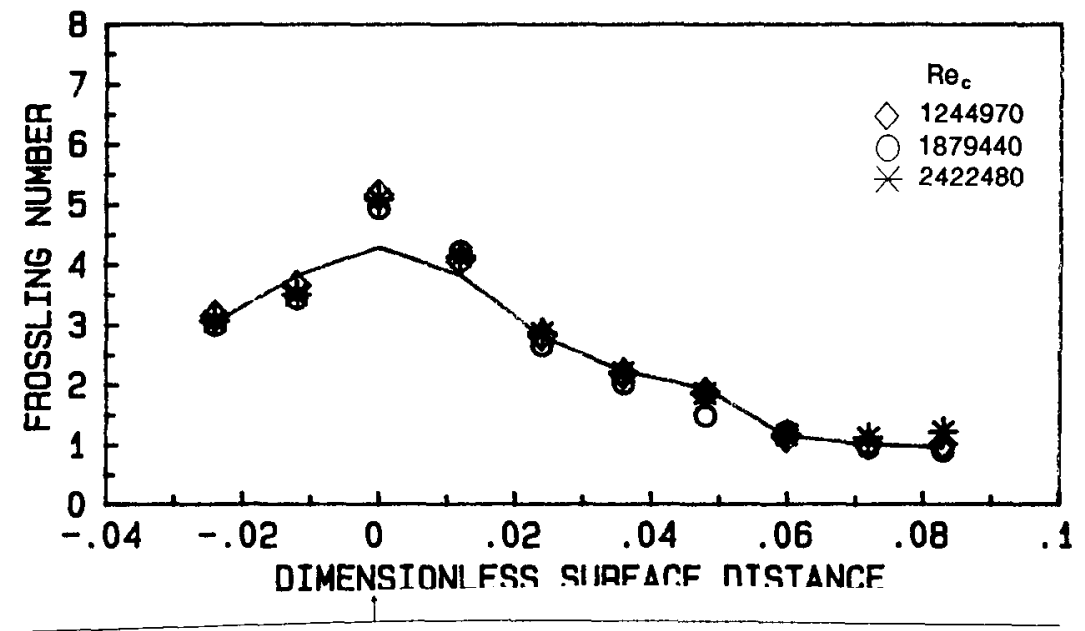

Figure 11. Frossling number based on chord for leading edge rougnened airfoil, four degree angle of attack for various Reynolds numbers. 


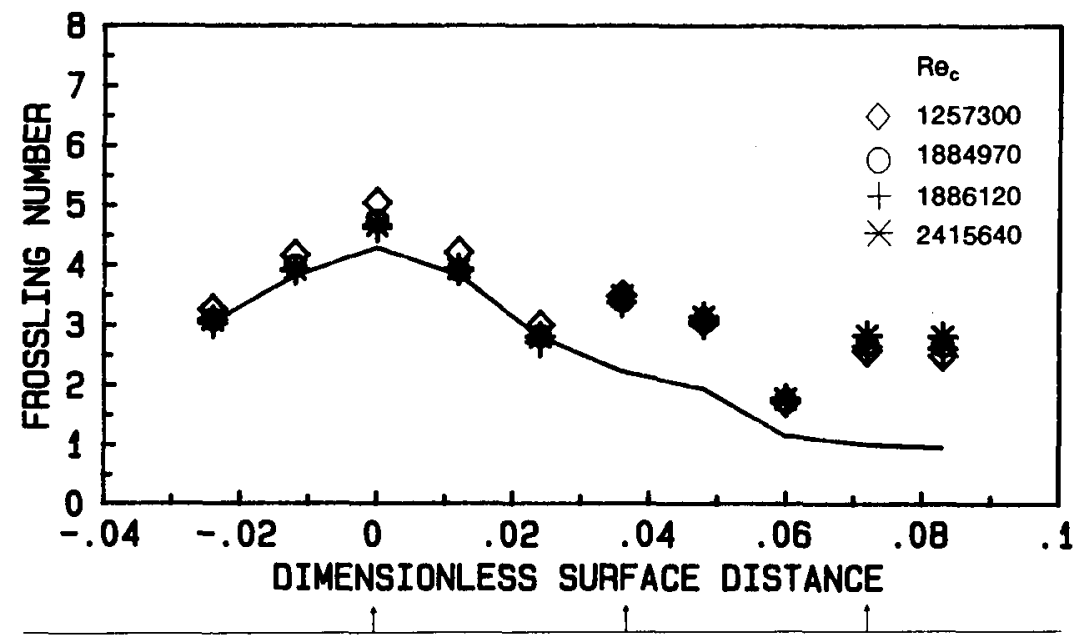

Figure 12. Frossling number based on chord for sparsely roughened airfoil, zero degree angle of attack for various Reynolds numbers.

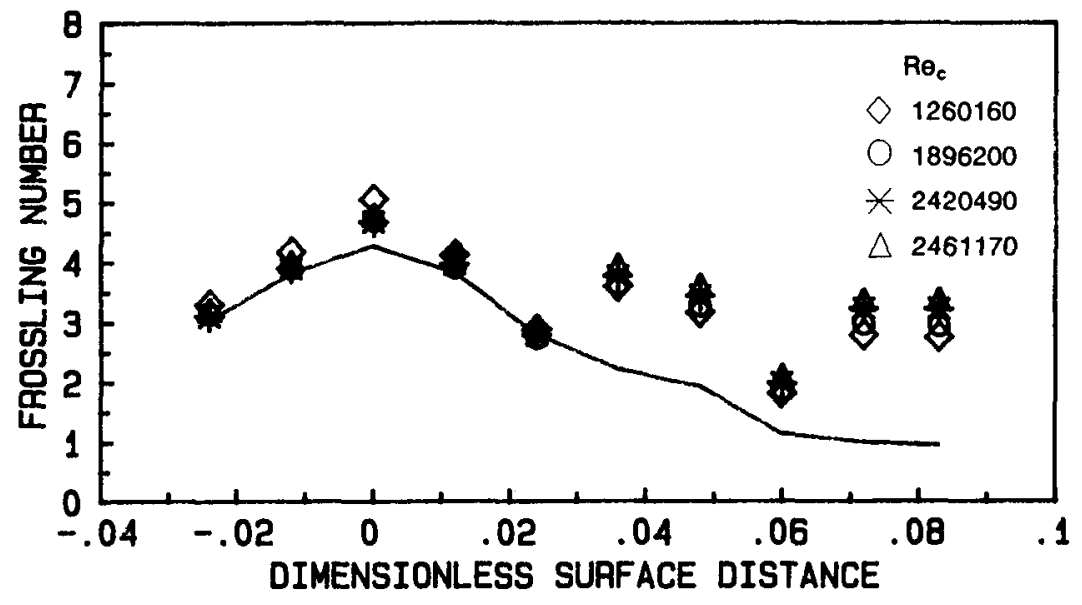

Figure 13. Frossling number based on chord for sparsely roughened airfoil, two degree angle of attack for various Reynolds numbers.

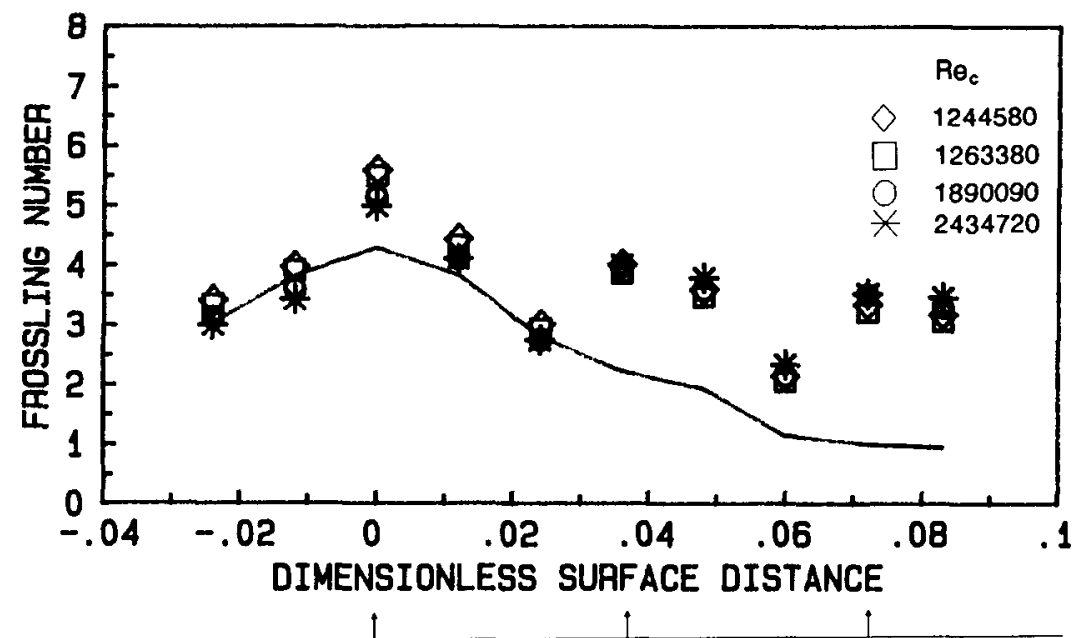

Figure 14. Frossling number based on chord for sparsely reoughened airfoil, four degree angle of attack for various Reynolds numbers. 


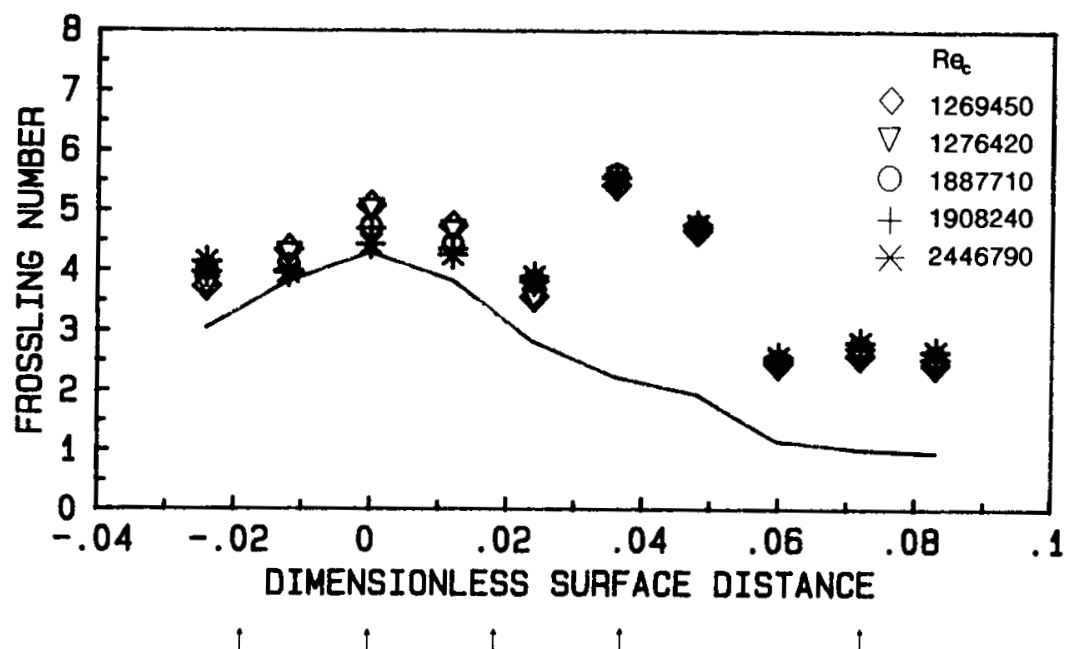

Figure 15. Frossling number based on chord for densely roughened airfoil, zero degree angle of attack for various Reynolds numbers.

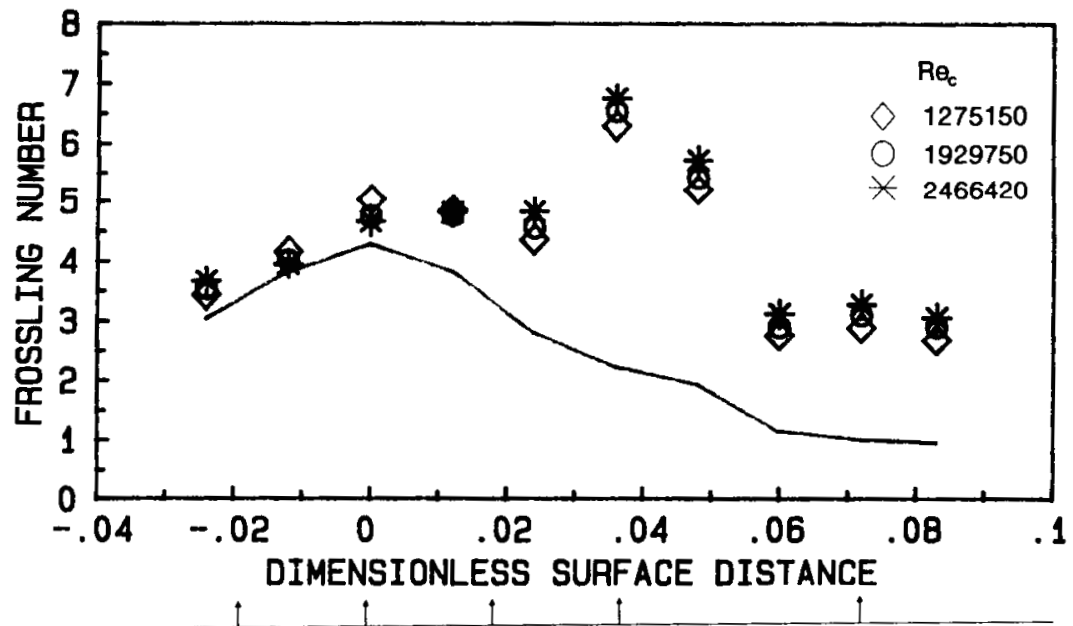

Figure 16. Frossling number based on chord for densely roughened airfoil, two degree angle of attack for various Reynolds numbers.

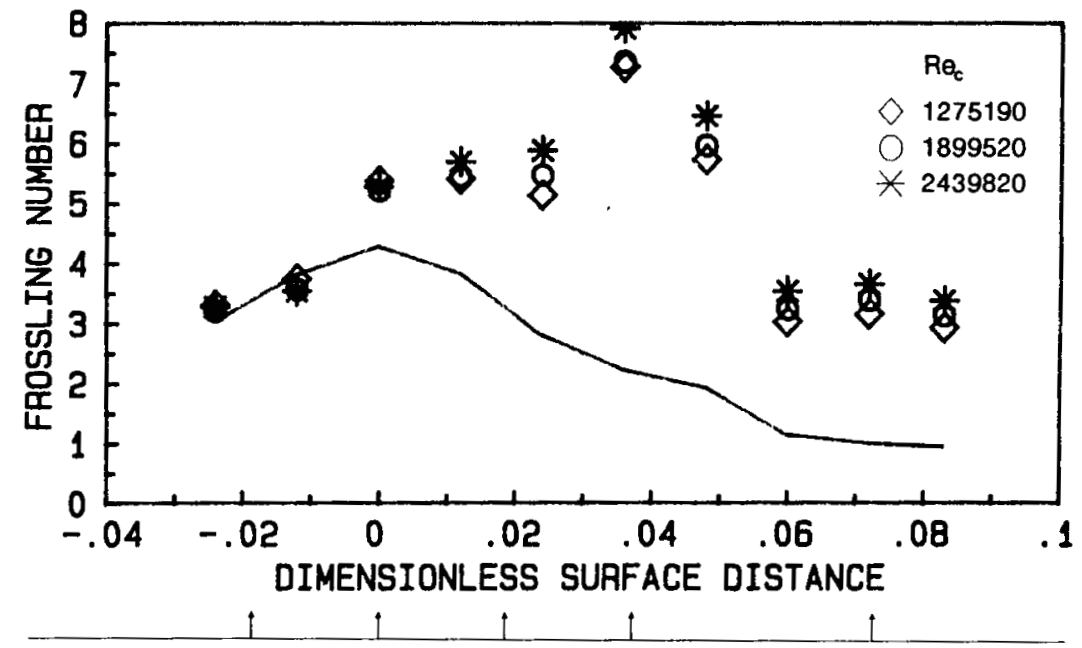

Figure 17. Frossling number based on chord for densely roughened airfoil, four degree angle of attack for various Reynolds numbers. 


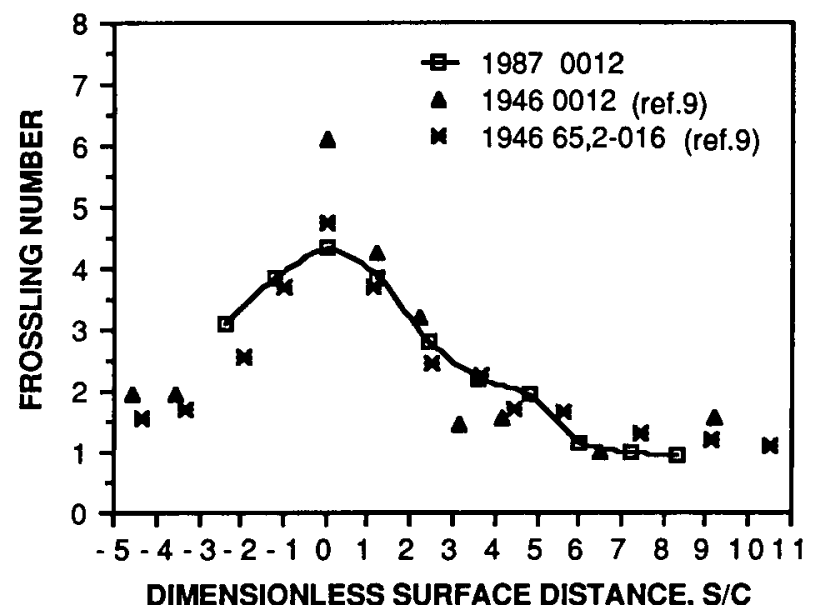

Figure 18. Comparison of NASA 1987 smooth airfoil data with flight test data of reference 9 .

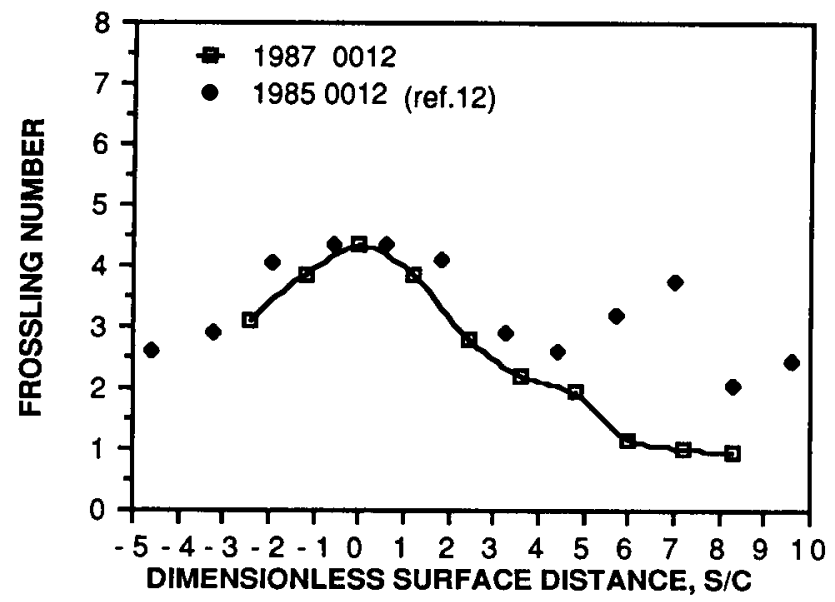

Figure 19. Comparison of NASA 1987 smooth airfoil data with wind tunnel data of reference 12. 


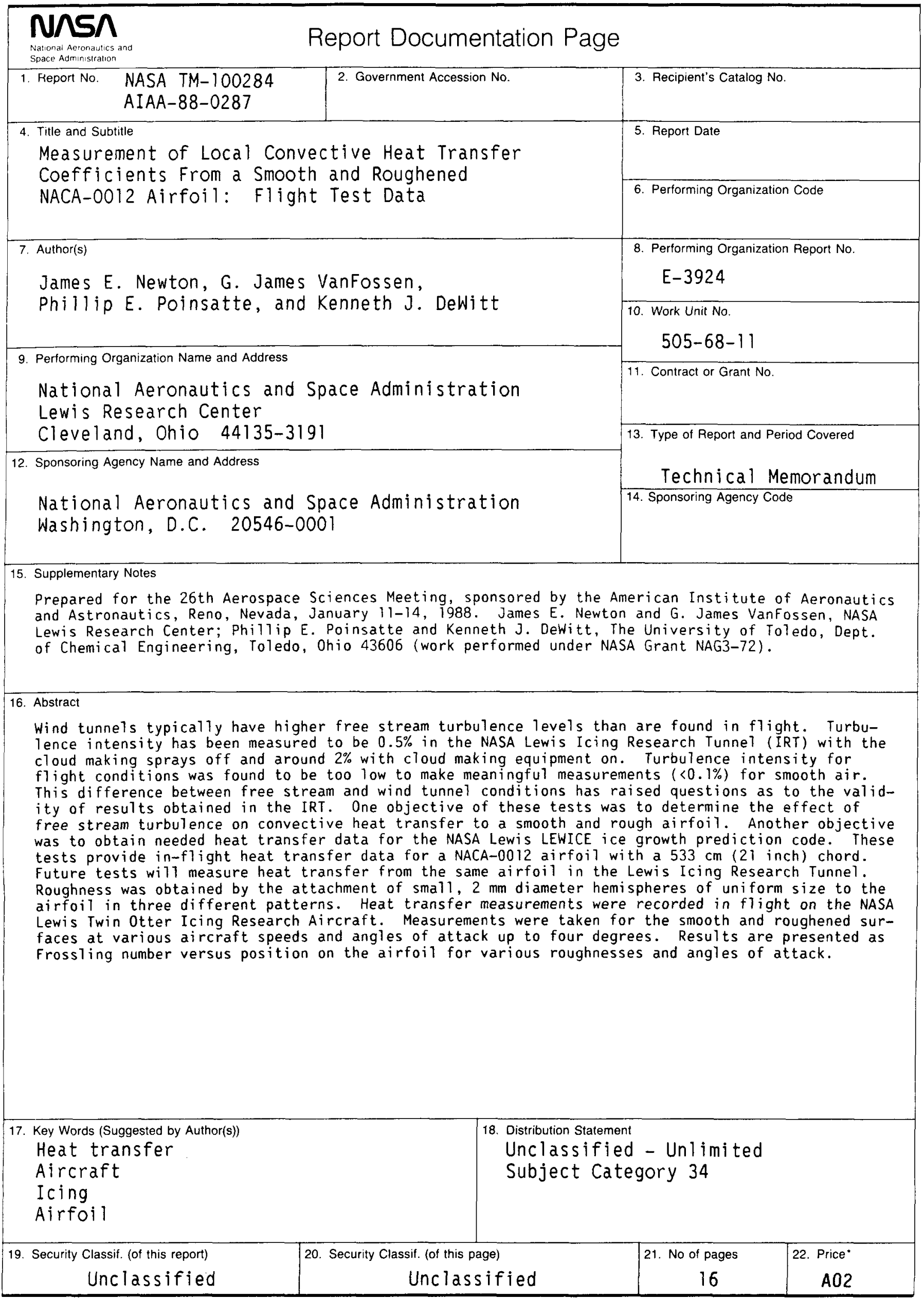

